\title{
PENGEMBANGAN BAHAN AJAR E-LEARNING BERBASIS EDMODO PADA MATERI LITOSFER KELAS X SMA
}

\author{
Dedi Sasmito Utomo ${ }^{1}$, Sumarmi ${ }^{2}$, dan Singgih Susilo ${ }^{3}$ \\ E-mail: dedisasmito@yahoo.com, sumarmi.fis@um.ac.id, \\ singgih.susilo.fis@um.ac.id
}

\begin{abstract}
The objective of this research and development is to produce: (1) E learning materials based on the material Edmodo lithosphere grade X, (2) virtual classroom Edmodo, and (3) Edmodo guide books for teachers and students. Data were collected by using a validation sheet and questionnaire. Qualitative data are derived from expert validation of material, language, and learning design, while quantitative data derived from student questionnaires. Results of the research are: (1) E learning instructional materials contained in the web categorized of well, (2) the virtual classroom Edmodo contained at the http://edmodo.com/dedisasmito, and (3) guide book Edmodo entitled "learning Edmodo with Easy". The development of e learning teaching materials are not limited to lithospheric material, but can be applied to other geographic materials.
\end{abstract}

Keywords: teaching materials, e-learning, Edmodo, lithosphere

\section{PENDAHULUAN}

Salah satu masalah yang terdapat dalam pembelajaran geografi yaitu kurangnya bahan ajar yang berkualitas sehingga menyebabkan pencapaian kompetensi pada siswa tidak optimal. Berkaitan dengan itu, Leo Ann Mean (dalam Raman, 2006) mengemukakan beberapa sebab yang mengakibatkan pencapaian siswa dalam mata pelajaran geografi semakin menurun, salah satunya karena bahan ajar yang kurang berkualitas. Beberapa bagian yang menjadi sebab bahan ajar tidak berkualitas terletak pada substansi materi, kebahasaan, dan desain pembelajaran.

Dari segi substansi materi, bahan ajar yang digunakan membutuhkan media untuk memperjelas penyampaian pesan. Media juga berfungsi sebagai pengganti

\footnotetext{
${ }^{1}$ Mahasiswa Pasca Sarjana UM

${ }^{2}$ Dosen Jurusan Geografi UM

${ }^{3}$ Dosen Jurusan Geografi UM
}

fenomena geosfer di dalam pembelajaran. Hal ini sangat penting karena tidak semua fenomena geosfer dapat dibawa ke dalam pembelajaran di kelas. Sebaliknya, pembelajaran geografi sangat sulit dibahas tanpa melibatkan lingkungan sebenarnya. Berkaitan dengan itu, Sumarmi (2012) menyatakan bahwa pembelajaran geografi sulit dibahas hanya secara teoritis di kelas, tetapi perlu menghubungkan dengan kondisi sebenarnya. Oleh karena itu, untuk menghubungkan pembelajaran di kelas dengan lingkungan sebenarnya, media sangat diperlukan.

Hal selanjutnya yang dibutuhkan untuk menghasilkan bahan ajar yang berkualitas, yakni tata bahasa yang baik. Aspek kebahasaan termasuk bagian 
Dedi Sasmito Utomo, Sumarmi, Singgih Susilo. Pengembangan Bahan Ajar E-Learning Berbasis Edmodo Pada Materi Litosfer Kelas X SMA

penting dalam bahan ajar. Jika tata bahasanya baik, maka pesan yang ingin disampaikan jelas sehingga mudah dipahami oleh pembaca. Bahan ajar yang baik mengandung kalimat efektif yang tidak membingungkan pembaca. Sejalan dengan itu, Suwignyo dan Santoso (2008) menjelaskan bahwa jika pembaca masih mengalami kebingungan dan kesulitan yang mengakibatkan salah menafsirkan pesan kalimat, maka kalimat tersebut belum dikategorikan efektif.

Bagian terakhir untuk menghasilkan bahan ajar yang berkualitas adalah dengan menyusun desain pembelajaran yang baik. Bahan ajar yang berkualitas mampu memuat semua jenis media, baik yang statis maupun dinamis seperti animasi dan video. Bahan ajar yang memiliki kemampuan demikian adalah bahan ajar e-learning. Kemampuan bahan ajar e-learning dalam menyajikan media dinamis merupakan kelebihan yang tidak dimiliki oleh media cetak. Sejalan dengan itu, Rusman (2013) menyatakan bahwa bahan ajar e-learning baik untuk pembelajaran karena memiliki kelebihan yang tidak dimiliki media kertas ataupun media yang lain. Kelebihan tersebut amat penting terutama dalam menyajikan materi litosfer.

Materi litosfer dapat dikelompokkan menjadi empat, yaitu: (1) struktur lapisan bumi, (2) batuan, (3) tenaga endogen, dan (4) tenaga eksogen. Masing-masing topik termasuk jenis materi yang melibatkan proses seperti pembentukan batuan beku, pergerakan lempeng tektonik, pergerakan magma, dan pelapukan batuan. Untuk menggambarkan fenomena tersebut, yang paling tepat dan mudah dipahami oleh siswa dengan menggunakan media bergerak seperti animasi dan video. Adapun bahan ajar yang dapat memuat keduanya yaitu bahan ajar $e$-learning.

Bahan ajar e-learning dipillih karena memiliki kelebihan dibanding bahan ajar jenis lainnya. Kelebihan pertama, bahan ajar e-learning dapat memadukan antara teks dengan media bergerak seperti animasi dan video. Perpaduan tersebut sangat bermanfaat bagi siswa karena bahan ajar ditampilkan secara utuh dengan kombinasi media yang lebih lengkap daripada bahan ajar cetak. Siswa menjadi lebih mudah memahami karena media bergerak mampu menggambarkan seperti lingkungan sebenarnya.

Kelebihan kedua, bahan ajar e-learning dapat dimanfaatkan secara flesksibel. Flesibilitas bahan ajar e-learning yang ditampilkan di dalam web dapat dimanfaatkan tanpa terikat tempat dan waktu. Sejalan dengan hal itu, Plucker (2014) mengungkapkan bahwa situs atau web merupakan "teks hidup" yang dapat digunakan secara fleksibel sebagai sumber daya pedagogis dalam program mandiri yang berfokus pada kecerdasan.

Kelebihan ketiga, pemanfaatan bahan ajar e-learning untuk pembelajaran dapat meningkatkan kualitas belajar siswa. Mamentu (2013) dalam penelitiannya menyebutkan, sebanyak $78,5 \%$ siswa dapat meningkatkan kualitas belajar dengan menggunakan bahan ajar e-learning. Hasil tersebut dipengaruhi oleh indikator-indikator yang meliputi: kualitas web, penyajian materi, interaksi program, interaksi user, panduan, desain pembelajaran, dan fasilitas e-learning. Hasil penelitian lain diungkapkan oleh Sudibyo (2013) yang menyatakan bahwa 
hasil belajar siswa setelah menggunakan Edmodo Blog Education, nilai kognitif siswa cukup meningkat dibandingkan sebelumnya menjadi $76,05 \%$.

Kelebihan keempat, bahan ajar e-learning dapat bekerja secara otomatis karena dapat diintegrasikan dengan Learning Management System (LMS). Hal ini karena LMS begitu mudah, fleksibel, dan nyaman. Morris (2012) mengungkapkan bahwa daya tarik menggunakan $L M S$ adalah metode yang fleksibel dan nyaman dalam memberikan pendidikan online. Sistem tersebut memudahkan guru dan siswa dalam pembelajaran mulai persiapan, tahap pelaksanaan, sampai evaluasi. Pada saat evaluasi, guru tidak perlu melakukan koreksi secara manual karena sudah dilakukan secara otomatis oleh LMS. Salah satu LMS yang digunakan adalah Edmodo.

Pemilihan Edmodo sebagai aplikasi untuk memanfaatkan bahan ajar e-learning didasarkan pada kegemaran siswa dalam mengakses jejaring sosial seperti Facebook. Edmodo termasuk situs mirip Facebook yang diperuntukkan untuk pembelajaran. Situs tersebut gratis dan mudah digunakan selama guru dan siswa bisa terhubung dengan internet. Berdasarkan uraian permasalahan di atas, maka perlunya pengembangan bahan ajar e-learning pada materi litosfer dengan memanfaatkan Edmodo.

Pengembangan bahan ajar ini didasarkan pada model pengembangan bahan ajar berbasis web yang dikembangkan oleh SEAMOLEC. Alasan dalam memilih model tersebut karena SEAMOLEC memiliki kredibilitas dalam pengembangan bahan ajar berbasis web.

\section{METODE PENELITIAN DAN PENGEMBANGAN}

\section{Model Penelitian}

Penelitian dalam pengembangan bahan ajar e-learning ini menggunakan model Borg \& Gall (2003). Model ini memiliki 10 langkah yang dimodifikasi dan dikelompokkan menjadi 3 tahap, yaitu: tahap (1) studi pendahuluan (research and information collecting), tahap (2) pengembangan (planning and development of the preliminary form of product), dan tahap (3) uji cob (preliminary field testing, main product revision, main field testing).

Penentuan modifikasi didasarkan atas pertimbangan bahwa tujuan penelitian ini untuk satu topik bahasan, yaitu litosfer. Pengembangan untuk semua materi dalam geografi tidak memungkinkan karena peneliti memiliki keterbatasan waktu dalam penelitian. Selain itu, dalam pengembangan produk ini ada beberapa tahap yang tidak perlu dilakukan seperti: uji coba kelayakan dan diseminasi. Uji coba kelayakan tidak perlu dilakukan karena uji coba kelompok kecil dan kelompok besar sudah dapat mewakili tanggapan subjek penelitian. Adapun tahap diseminasi tidak perlu dilakukan karena penelitian difokuskan pada pengembangan produk, sedangkan diseminasi dapat dilakukan oleh peneliti lain.

Model Borg \& Gall dipilih karena prosedurnya jelas, sistematis, dan memiliki keleluasaan untuk tidak diterapkan semua. Penelitian dan pengembangan ini terbatas sampai menghasilkan produk berupa bahan ajar e-learning. Bahan ajar yang 
Dedi Sasmito Utomo, Sumarmi, Singgih Susilo. Pengembangan Bahan Ajar E-Learning

Berbasis Edmodo Pada Materi Litosfer Kelas X SMA

dikembangkan difokuskan pada materi litosfer. Model penelitian Borg \& Gall yang sudah dimodifikasi lebih jelasnya dapat dilihat pada gambar 1 di bawah ini.

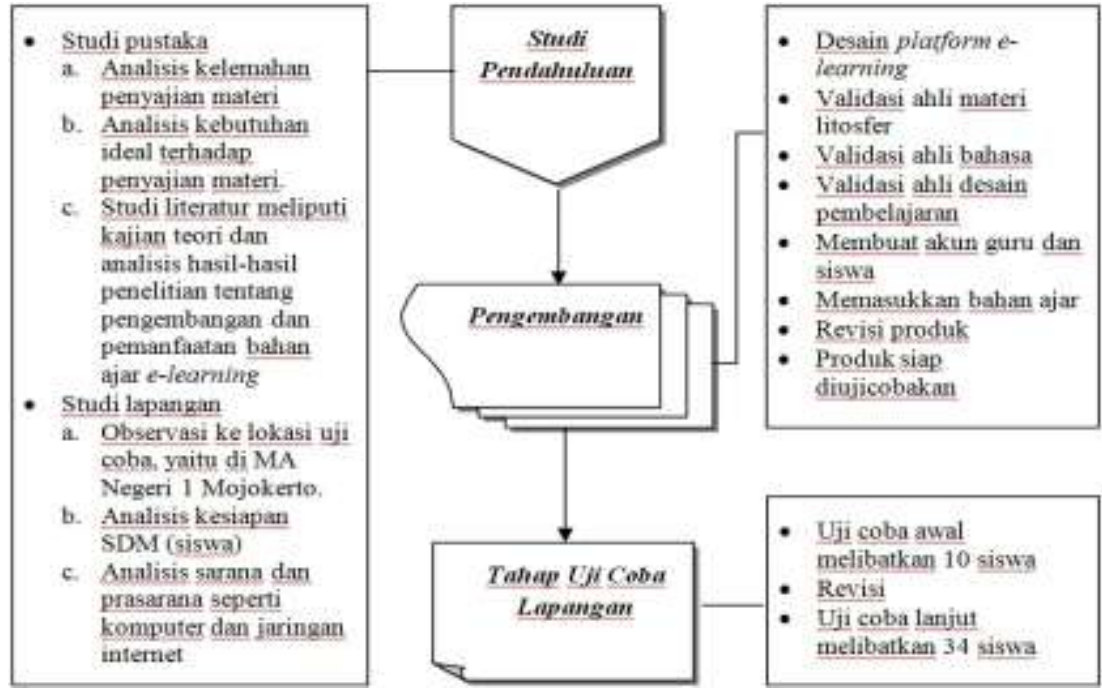

Gambar 1. Diagram Alur R\&D Hasil Modifikasi Model Borg \& Gall (2003)

Tahap studi pendahuluan terdiri dari studi pustaka dan lapangan. Studi pustaka meliputi hal-hal berikut: (1) analisis kelemahanpenyajian materi, (2) analisis kebutuhan penyajian materi, dan (3) studi literatur tentang hasil-hasil penelitian dan pengembangan bahan ajar e-learning. Adapun studi lapangan meliputi hal-hal berikut: (1) observasi lokasi uji coba, (2) analisis kesiapan SDM, (3) analisis sarana penunjang uji coba misalnya komputer dan jaringan internet.

Tahap selanjutnya dari penelitian ini adalah pengembangan yang meliputi tiga langkah, yaitu: (1) penyusunan bahan ajar, (2) validasi ahli, dan (3) penyusunan kelas virtual Edmodo. Penyusunan bahan ajar dilakukan secara online. Selanjutnya, bahan ajar divalidasi oleh ahli materi, bahasa, dan desain pembelajaran.

Hasil validasi digunakan untuk memperbaiki bahan ajar. Pada tahap akhir pengembangan, bahan ajar ditampilkan di dalam kelas virtual Edmodo.

Tahap akhir dari penelitian ini adalah uji coba yang terdiri dari dua uji coba yaitu uji coba kelompok kecil dan besar. Uji coba kelompok kecil terdiri dari 10 siswa, sedangkan uji coba kelompok besar terdiri dari 34 siswa. Penentuan subjek uji coba dipilih berdasarkan kemampuan IT dan kognitif yang rendah. Alasannya, jika bahan ajar ini mampu diterima oleh siswa dengan kemampuan IT dan kognitif yang rendah, maka siswa yang kemampuan IT dan kognitifnya lebih tinggi semakin mudah memahami.

\section{Model Pengembangan}

Pengembangan bahan ajar $e$-learning berbasis Edmodo dengan materi litosfer ini didasarkan pada model pengembangan bahan ajar berbasis web yang dikembangkan oleh SEAMOLEC. Alasan 
dalam memilih model tersebut adalah karena SEAMOLEC sebagai lembaga yang bergerak dalam pengembangan pendidikan jarak jauh di Asia Tenggara sudah memiliki kredibilitas dalam pengembangan bahan ajar berbasis web. Model pengembangan ini dikelompokkan menjadi 4 tahap, yaitu: penyusunan bahan ajar, pembuatan akun guru dan siswa, penyajian bahan ajar, dan penyusunan evaluasi. Penyusunan bahan ajar dimuat dalam http://dedisasmito.web.id. Adapun pembuatan akun guru dan siswa, penyajian bahan ajar, dan penyusunan evaluasi di dalam Edmodo.

\section{Uji Coba Produk}

Uji coba produk dilaksanakan setelah melalui tahap validasi oleh ahli. Validasi ahli terdiri: (1) dosen Pendidikan Geografi Universitas Negeri Malang untuk validasi materi, (2) guru besar Sastra dan Bahasa Indonesia Universitas Negeri Malang untuk validasi kebahasaan, dan (3) guru besar Teknologi Pembelajaran Universitas Negeri Malang untuk validasi desain pembelajaran. Para ahli memberikan penilaian untuk dijadikan perbaikan terhadap produk. Adapun produk yang sudah diperbaiki dapat diujicobakan pada kelompok kecil dan besar.

Tahap validasi dan uji coba produk bertujuan untuk mengetahui kelayakan produk. Penilaian hasil validasi bersifat kualitatif berupa masukan dalam bentuk komentar yang dituangkan pada tiap item pertanyaan di lembar validasi. Adapun data respon siswa bersifat kuantitatif. Data respon siswa diperoleh melalui angket berupa Skala Lickert dan dianalisis dengan statistik deskriptif, yaitu persentase skor pada tiap item pertanyaan.

\section{HASIL DAN PEMBAHASAN}

Hasil pengembangan dalam kegiatan penelitian ini berupa teks bahan ajar geografi yang dimuat secara online di dalam web pada materi litosfer dengan alamat http://dedisasmito.web.id. Materi bahan ajar yang dikembangkan terdiri dari struktur lapisan bumi, batuan, tenaga endogen, dan tenaga eksogen. Bahan ajar tersebut diintegrasikan dengan media seperti gambar, animasi, dan video sehingga dapat lebih memudahkan siswa dalam memahami materi litosfer.

Uji coba produk dilaksanakan di MAN 1 Kota Mojokerto. Uji coba ini dilakukan pada kelompok kecil dan besar. Uji coba kelompok kecil terdiri dari 10 siswa, sedangkan uji coba kelompok besar melibatkan 34 siswa. Uji coba produk ini untuk mengetahui kelayakan produk melalui respon yang diberikan oleh siswa. Adapun hasil uji coba pada kelompok kecil dan besar dapat diamati seperti di bawah ini. 
Dedi Sasmito Utomo, Sumarmi, Singgih Susilo. Pengembangan Bahan Ajar E-Learning Berbasis Edmodo Pada Materi Litosfer Kelas X SMA

Tabel 2. Hasil Uji Coba Kelompok Kecil dan Kelompok Besar

\begin{tabular}{|c|c|c|c|c|c|c|}
\hline \multirow{2}{*}{ No } & \multirow{2}{*}{ Indikator } & \multirow{2}{*}{$\begin{array}{l}\text { Jumlah } \\
\text { Soal }\end{array}$} & \multicolumn{2}{|c|}{ Kelompok Kecil } & \multicolumn{2}{|c|}{ Kelompok Besar } \\
\hline & & & $\%$ & Kategori & $\%$ & Kategori \\
\hline & Kualitas situs & 10 & 75,8 & Baik & 74,6 & Baik \\
\hline & web/teknologi & & & & & \\
\hline & Penyajian materi & 10 & 79,2 & Baik & 73,1 & Baik \\
\hline & Interaksi program & 5 & 86,8 & Sangat Baik & 74,4 & Baik \\
\hline & Interaksi pemakai & 6 & 74,6 & Baik & 71,4 & Baik \\
\hline & Desain pembelajaran & 6 & 81,0 & Sangat Baik & 76,3 & Baik \\
\hline & $\begin{array}{l}\text { Panduan penggunaan } e \text { - } \\
\text { learning }\end{array}$ & 6 & 75,3 & Baik & 71,3 & Baik \\
\hline & Fasilitas Edmodo & 7 & 76,0 & Baik & 71,8 & Baik \\
\hline$\sum$ & & 50 & 78,04 & & 73,3 & \\
\hline
\end{tabular}

Berdasarkan hasil uji coba menunjukkan ada perbedaan antara uji coba kelompok kecil dengan uji coba kelompok besar. Meskipun dikategorikan baik, namun secara umum ada penurunan sebesar 4,7\%. Hasil uji coba kelompok kecil mendapatkan skor total 78,04\%, sedangkan hasil uji coba kelompok besar skor total yang diperoleh adalah $73,3 \%$. Penurunan perolehan skor total pada uji coba dipengaruhi oleh beberapa faktor antara lain, yaitu: (1) kemampuan subjek uji coba dalam TIK, (2) kualitas jaringan internet, (3) sarana yang dipakai dalam mengakses bahan ajar e-learning, dan (4) adanya persepsi like and dislike terhadap pembelajaran e-learning.

Penurunan hasil yang diperoleh pada uji coba kelompok kecil dan kelompok besar dipengaruhi oleh kemampuan subjek uji coba pada bidang TIK. Pada uji coba kelompok kecil, subjek uji coba memiliki kemampuan terhadap komputer dan internet sangat baik. Atas dasar tersebut, penilaian terhadap kualitas web juga baik. Hal ini dilatarbelakangi oleh intensitas browsing yang cukup tinggi sehingga terbiasa dengan tampilan bacaan di internet. Persepsi itulah yang menimbulkan rasa suka pada saat membaca bahan ajar di web. Sebaliknya, subjek uji coba kelompok besar memiliki kemampuan yang beragam sehingga hasilnya tidak sebaik pada uji coba kelompok kecil.

Penilaian terhadap kualitas web dipengaruhi juga oleh koneksi internet. Web akan tampil sempurna jika diakses dengan jaringan internet yang baik. Sebaliknya, web sulit tampil sempurna jika diakses di lokasi yang jaringan internetnya kurang baik. Pada uji coba kelompok kecil dilakukan di sekolah yang memiliki jaringan internet baik. Adapun pada uji coba kelompok besar dilakukan di tempat tinggal masingmasing subjek uji coba dengan kualitas jaringan internet yang beragam, ada yang baik dan ada yang kurang baik.

Sarana yang dipakai mengakses juga mempengaruhi tampilan web. Hal ini disebabkan adanya perbedaan antara versi desktop dengan mobile. Pada uji coba kelompok kecil, subjek uji coba menggunakan komputer sehingga tampilan web terlihat sempurna, sedangkan pada uji coba kelompok besar subjek uji coba ada yang menggunakan 
handphone sehingga yang dilihat versi mobile. Berdasarkan kondisi tersebut, penilaian terhadap web tidak sebaik pada saat uji coba kelompok kecil.

Faktor terakhir yang menyebabkan terjadinya penurunan penilaian terhadap bahan ajar e-learning adalah karena faktor like dan dislike. Keberagaman kemampuan subjek uji coba terhadap bidang IT berpengaruh terhadap penilaian bahan ajar tersebut. Subjek uji coba yang suka terhadap dunia internet memberikan penilaian yang baik. Hal ini terjadi pada uji coba kelompok kecil karena subjek uji coba dipilih bagi siswa yang memiliki pengetahuan dan terampil dalam dunia internet. Adapun pada uji coba kelompok besar, kemampuan subjek uji coba dalam bidang IT lebih beragam sehingga bagi siswa yang tidak terbiasa dengan bacaan online tidak menyukai hal tersebut. Akibatnya, penilaian yang diberikan tidak sebaik pada saat uji coba kelompok kecil.

\section{KESIMPULAN}

Produk pengembangan ini berupa bahan ajar e-learning dengan materi litosfer. Produk ini dilengkapi buku pedoman yang berjudul "Belajar Edmodo dengan Mudah". Segala aktivitas yang berkaitan dengan uji coba produk ini tertuang dalam kelas virtual Edmodo.

Bahan ajar e-learning ini telah direvisi berdasarkan hasil penilaian validator ahli dan uji coba pada kelompok kecil dan besar. Validator ahli terdiri atas dosen Geografi UM, guru besar Teknologi Pembelajaran UM, dan guru besar Sastra dan Bahasa Indonesia UM. Uji kelompok kecil dilakukan pada 10 siswa dan uji coba kelompok besar melibatkan 34 siswa MAN 1 Mojokerto.

Berdasarkan persentase kevalidan yang diperoleh uji coba kelompok kecil dan besar, bahan ajar e-learning pada materi litosfer yang dikembangkan telah memenuhi kriteria valid. Oleh karena itu, bahan ajar e-learning ini layak sudah digunakan. Revisi produk dilakukan berdasarkan komentar dan saran yang diberikan oleh validator.

\section{DAFTAR RUJUKAN}

Borg, W. R. Gall, M. D. \& Gall, J. P. 2003. Educational Research: An Introduction. New York: Longman Inc.

Mamentu, F. Y. 2013. Pengaruh Penggunaan media Pembelajaran Online Edmodo Terhadap Hasil Belajar Siswa Kelas XI Pada Mata Pelajaran TIK Di SMAN 1 Tondano. Jurnal Ilmiah Engineering and Education, Vol 1, No 4, (Online), (http://ejournal.unima.ac.id/index.p hp/Fatek/article/view/1485), diakses 7 Juni 2014.

Morris, M., Balderson, D. \& Matthew, M. 2012. Using an Online Learning Management System for Coaching. The Journal of Physical Education, Recreation \& Dance 83.4: 50+. Gale Education, Religion and $\mathrm{Hu}-$ manities Lite Package, (Online), (http://go.galegroup.com/ps/i.do?id $=\mathrm{GALE} \%$ 7CA287517844\&v=2.1\&u=ptn058 \&it=r\&p=SPJ.SP01\&sw=w\&asid= 54343a63fa1335b208f8611c1b247f 2d), diakses 29 Januari 2014.

Plucker, J. A., \& Esping, A. 2014. Developing and maintaining a website for teaching and learning about intelligence. Intelligence 42: 171+. Gale Education, Religion and $\mathrm{Hu}-$ 
Dedi Sasmito Utomo, Sumarmi, Singgih Susilo. Pengembangan Bahan Ajar E-Learning

Berbasis Edmodo Pada Materi Litosfer Kelas X SMA

manities Lite Package, (Online), (http://go.galegroup.com/ps/i.do?id $=\mathrm{GALE} \% 7 \mathrm{CA} 355504928 \& \mathrm{~V}=2.1$ $\& \mathrm{u}=\mathrm{ptn} 058 \& \mathrm{it}=\mathrm{r} \& \mathrm{p}=\mathrm{SPJ} . \mathrm{SP} 01 \& \mathrm{~s}$ $\mathrm{w}=\mathrm{w} \& \mathrm{asid}=\mathrm{f0f} 401 \mathrm{c} 348 \mathrm{fe} 7 \mathrm{c} 727 \mathrm{c} 0 \mathrm{~b}$ 95b2e68f3723), diakses 28 Januari 2014.

Raman, A. 2006. Kesan Peta Animasi dan Interaktif dalam Pengajaran dan Pembelajaran Geografi. Universiti Sains Malaysia.

Rusman. 2013. Model-Model Pembelajaran: Mengembangkan Profesionalisme Guru. Jakarta: Rajawali Press.

Sudibyo, W. 2013. Penggunaan Media Pembelajaran Fisika dengan ELearning Berbasis Edmodo Blog Education Pada Materi Alat Optik untuk Meningkatkan Respons Motivasi dan Hasil Belajar Siswa Di SMPN 4 Surabaya. Jurnal Inovasi Pendidikan Fisika Vol. 02 No. 03 Tahun 2013, 187.

Sumarmi. 2012. Model-Model Pembelajaran Geografi. Malang: Aditya Media Publishing.

Suwignyo, H. \& Santoso, A. 2008. Bahasa Indonesia Keilmuan. Malang: UM Press. 